\title{
Effect of Gastrin I and II on the Secretion of Intrinsic Factor
}

\author{
A. G. WANGEL,* M.D., M.R.A.C.P. ; SHEILA T. CALLENDER,* M.D., F.R.C.P.
}

Brit. med.f., 1965, 1, 1409-1411

Estimation of gastric acidity has long been regarded as an essential investigation in patients in whom pernicious anaemia is suspected. Gruel, alcohol, insulin, and small doses of histamine which were earlier used to enhance gastric secretion have been replaced by the augmented histamine test meal introduced by Kay (1953).

The introduction of methods for direct assay of the content of intrinsic factor in gastric juice (Castro and Glass, 1962 ; Sullivan et al., 1962; Abels et al., 1963; Ardeman and Chanarin, 1963 ; Jeffries et al., 1963) has added to the importance of the test meal. The diagnosis of deficiency of intrinsic factor, hitherto made on the grounds of malabsorption of radioactive vitamin $B_{12}$ correctable by intrinsic factor, can now be confirmed by a test in vitro. Moreover, by such assay of intrinsic factor it should be possible to detect lesser degrees of impairment of secretion than can be shown by tests of vitamin- $B_{12}$ absorption.

Gregory and Tracey (1964) isolated two forms of the hormone gastrin from hog antral mucosa. Makhlouf et al. (1964) showed that in terms of stimulating the secretion of gastric acid in man gastrin II was even more effective than the augmented histamine test. Since gastrin is not only a powerful stimulant of acid secretion but also lacks the unpleasant side-effects of histamine (Makhlouf et al., 1964), it appears likely to come into wide use both in clinical research and in routine clinical investigation.

Histamine is known to enhance the secretion of intrinsic factor (Ardeman et al., 1964). It therefore seemed appropriate to ascertain whether gastrin had a similar qualitative and quantitative action. This paper describes the effect of gastrin

* From the Nuffield Department of Clinical Medicine, the Radcliffe Infirmary, Oxford. and of histamine on the secretion of gastric acid and intrinsic factor in five normal subjects.

\section{Methods}

The preparation of gastrin was a combination of gastrin I and II manufactured by Leo Pharmaceutical Products of Copenhagen (Batch 64121). It was dispensed in 2-ml. ampoules containing $150 \mu \mathrm{g}$. each.

Five healthy members of the hospital staff each underwent a series of five test meals. After an overnight fast, intubation was carried out in the morning. The stomach was emptied, this juice being discarded. The basal secretion was then collected for 30 minutes. Histamine or gastrin was then given and the gastric juice was collected for the next four successive 15-minute periods. Intermittent suction with a syringe was carried out at frequent intervals and attention was paid to constant patency of the tube. Saliva was expectorated into a bowl to avoid contamination of the gastric juice.

In the tests in which histamine was used as a stimulant mepyramine maleate was given intramuscularly in a dose of $50 \mathrm{mg}$. and followed 30 minutes later by $40 \mu \mathrm{g}$. of histamine acid phosphate per kg. body weight subcutaneously. In the four gastrin tests the gastrin was injected intramuscularly into the right deltoid muscle in amounts of $0.5,1.5,2.5$, and $3.5 \mu \mathrm{g} . / \mathrm{kg}$. body weight. The tests were done in random order with at least three days between two successive tests in any single subject.

As each specimen was collected an aliquot of the gastric juice was brought immediately to $p \mathrm{H} 7$ to 7.5 with $N \mathrm{NaOH}$ and centrifuged at 2,500 r.p.m. for 15 minutes. The super-

TABle I.-Effect of Histamine Acid Phosphate and Increasing Doses of Gastrin I and II on the Secretion of Intrinsic Factor (I.F.) and Acid. The Basal Secretion has been Calculated for 15 Minutes to Facilitate Comparison

\begin{tabular}{|c|c|c|c|c|c|c|c|c|c|c|c|c|c|}
\hline \multirow{3}{*}{$\begin{array}{l}\quad \text { Subject } \\
\text { Sex, } \\
\text { Age, and } \\
\text { Weight } \\
\end{array}$} & \multirow{3}{*}{ Stimulus } & \multirow{2}{*}{\multicolumn{2}{|c|}{$\begin{array}{c}\text { Basal } \\
\text { (Per } 15 \text { mins.) }\end{array}$}} & \multicolumn{8}{|c|}{ Fifteen-minute Periods } & \multirow{2}{*}{\multicolumn{2}{|c|}{$\begin{array}{c}\text { Total } \\
0-60 \text { mins. }\end{array}$}} \\
\hline & & & & \multicolumn{2}{|c|}{1} & \multicolumn{2}{|c|}{2} & \multicolumn{2}{|c|}{3} & \multicolumn{2}{|c|}{4} & & \\
\hline & & $\begin{array}{l}\text { I.F. } \\
\text { (Units) }\end{array}$ & $\underset{\text { (mEq) }}{\text { Acid }}$ & $\begin{array}{l}\text { I.F. } \\
\text { (Units) }\end{array}$ & $\underset{\text { (mEq) }}{\text { Acid }}$ & $\begin{array}{l}\text { I.F. } \\
\text { (Units) }\end{array}$ & $\underset{(\mathrm{mEq})}{\text { Acid }}$ & $\begin{array}{l}\text { I.F. } \\
\text { (Units) }\end{array}$ & $\underset{\text { (mEq) }}{\text { Acid }}$ & $\begin{array}{l}\text { I.F. } \\
\text { (Units) }\end{array}$ & $\underset{\text { (mEq) }}{\text { Acid }}$ & $\begin{array}{l}\text { I.F. } \\
\text { (Units) }\end{array}$ & $\begin{array}{c}\text { Acid } \\
(\mathrm{mEq})\end{array}$ \\
\hline $\begin{array}{l}\text { B } \\
\text { Male } \\
\text { 30 years } \\
\text { Weight } 70 \mathrm{~kg} .\end{array}$ & 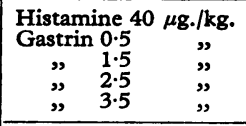 & $\begin{array}{l}2,100 \\
2,100 \\
1,500 \\
900 \\
2,100 \\
\end{array}$ & $\begin{array}{l}2 \cdot 4 \\
2 \cdot 3 \\
4 \cdot 6 \\
0 \cdot 9 \\
2 \cdot 3 \\
\end{array}$ & $\begin{array}{l}2,500 \\
2,800 \\
3,700 \\
2,100 \\
2,700 \\
\end{array}$ & $\begin{array}{l}2 \cdot 5 \\
3.9 \\
8 \cdot 8 \\
4 \cdot 6 \\
4 \cdot 9 \\
\end{array}$ & $\begin{array}{l}7,000 \\
2,800 \\
1,600 \\
4,600 \\
4,700\end{array}$ & $\begin{array}{r}8 \cdot 3 \\
5 \cdot 0 \\
10 \cdot 4 \\
9 \cdot 6 \\
11.0\end{array}$ & $\begin{array}{r}6,200 \\
3,100 \\
900 \\
1,400 \\
4,000\end{array}$ & $\begin{array}{r}18 \cdot 9 \\
6 \cdot 6 \\
7.4 \\
8 \cdot 5 \\
13 \cdot 3\end{array}$ & $\begin{array}{l}1,000 \\
1,600 \\
900 \\
1,700 \\
1,500\end{array}$ & $\begin{array}{l}9 \cdot 1 \\
8 \cdot 8 \\
5 \cdot 5 \\
7 \cdot 5 \\
9 \cdot 9\end{array}$ & $\begin{array}{r}16,700 \\
10,300 \\
7,100 \\
9,800 \\
12,900\end{array}$ & $\begin{array}{l}38 \cdot 8 \\
24 \cdot 3 \\
32 \cdot 1 \\
30 \cdot 2 \\
39 \cdot 1\end{array}$ \\
\hline $\begin{array}{l}\text { C } \\
\text { Male } \\
\text { 24 years } \\
\text { Weight } 72 \cdot 5 \mathrm{~kg} .\end{array}$ & $\begin{array}{ccc}\text { Histamine } 40 & \mu \mathrm{g} . / \mathrm{kg} . \\
\text { Gastrin } 0.5 & \text { " } \\
\# \quad 1.5 & \text { ” } \\
\# & 2.5 & \# \\
\# & 3.5 & \#\end{array}$ & $\begin{array}{r}500 \\
500 \\
1,000 \\
600 \\
800 \\
\end{array}$ & $\begin{array}{l}0.3 \\
0.8 \\
0.8 \\
0.8 \\
0.9 \\
\end{array}$ & $\begin{array}{l}3,500 \\
400 \\
3,300 \\
2,100 \\
3,500 \\
\end{array}$ & $\begin{array}{l}2.5 \\
0.6 \\
3.1 \\
2.4 \\
3.6 \\
\end{array}$ & $\begin{array}{r}4,400 \\
800 \\
2,600 \\
4,500 \\
4,500 \\
\end{array}$ & \begin{tabular}{r|}
10.7 \\
$4 \cdot 2$ \\
3.8 \\
6.8 \\
$8 \cdot 8$ \\
\end{tabular} & $\begin{array}{r}1,000 \\
600 \\
1,100 \\
1,700 \\
2,200 \\
\end{array}$ & $\begin{array}{r}7 \cdot 2 \\
2 \cdot 9 \\
4 \cdot 0 \\
8 \cdot 2 \\
10 \cdot 3 \\
\end{array}$ & $\begin{array}{r}300 \\
400 \\
1,200 \\
700 \\
1,300 \\
\end{array}$ & $\begin{array}{l}8 \cdot 9 \\
1 \cdot 6 \\
6 \cdot 7 \\
7 \cdot 0 \\
5 \cdot 3 \\
\end{array}$ & $\begin{array}{r}9,200 \\
2,200 \\
8,200 \\
9,000 \\
11,500 \\
\end{array}$ & $\begin{array}{l}29 \cdot 3 \\
9 \cdot 3 \\
17 \cdot 6 \\
24 \cdot 4 \\
28 \cdot 0 \\
\end{array}$ \\
\hline $\begin{array}{l}\mathrm{D} \\
\text { Male } \\
\text { 34 years } \\
\text { Weight } 85 \mathrm{~kg} .\end{array}$ & 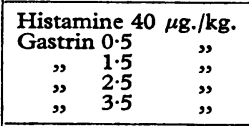 & $\begin{array}{c}1,100 \\
1,100 \\
500 \\
\text { Not } \\
900 \\
\end{array}$ & $\begin{array}{r}1.5 \\
1.4 \\
0.7 \\
\text { done } \\
0.1 \\
\end{array}$ & $\begin{array}{l}3,100 \\
1,900 \\
2,700 \\
1,900 \\
3,700 \\
\end{array}$ & $\begin{array}{l}3.5 \\
1.6 \\
3.4 \\
1.2 \\
4 \cdot 3 \\
\end{array}$ & $\begin{array}{l}, 100 \\
1,900 \\
2,400 \\
4,900 \\
5,100 \\
\end{array}$ & $\begin{array}{r}9.9 \\
2.3 \\
6.6 \\
11.3 \\
6.2 \\
\end{array}$ & $\begin{array}{r}2,000 \\
300 \\
1,900 \\
1,500 \\
3,800\end{array}$ & $\begin{array}{c}10.6 \\
1.8 \\
11.0 \\
11.7 \\
11.4\end{array}$ & $\begin{array}{r}200 \\
0 \\
500 \\
1,000 \\
1,900 \\
\end{array}$ & $\begin{array}{r}6.2 \\
1.5 \\
5.0 \\
8.5 \\
12.7 \\
\end{array}$ & $\begin{array}{r}10,400 \\
4,100 \\
7,500 \\
9,300 \\
14,500 \\
\end{array}$ & $\begin{array}{r}30 \cdot 2 \\
7.2 \\
26.0 \\
32.7 \\
34 \cdot 7 \\
\end{array}$ \\
\hline
\end{tabular}


natant was taken off and chilled to $+4^{\circ} \mathrm{C}$. The content of intrinsic factor was assayed later on the same day. The remainder of the specimen was used for electrometric measurement of $p \mathrm{H}$ and titration of acid with $0.1 \mathrm{~N} \mathrm{NaOH}$.

The assay of intrinsic factor was by a modification of the method of Ardeman and Chanarin (1963). Aliquots of $0.25 \mathrm{ml}$. of each sample of gastric juice were set up in two parallel rows of test-tubes. To one row was added $0.5 \mathrm{ml}$. of pooled normal serum, to the other $0.5 \mathrm{ml}$. of pooled serum collected from patients with pernicious anaemia who were known to have antibody to intrinsic factor. The antibody titre of this pooled serum was $\geqslant 300$ units $/ \mathrm{ml}$. The tubes were shaken and left for 20 minutes at room temperature, after which $1 \mathrm{ml}$. of a ${ }^{58} \mathrm{Co}$-vitamin- $\mathrm{B}_{12}$ solution containing $40 \mu \mathrm{g}$. ${ }^{58} \mathrm{Co}$-vitamin$\mathrm{B}_{12} / \mathrm{ml}$. was added. The tubes were again shaken and left for 20 minutes. Normal saline was added to make a final volume of $6 \mathrm{ml}$. After thorough mixing with $40 \mathrm{mg}$. of activated

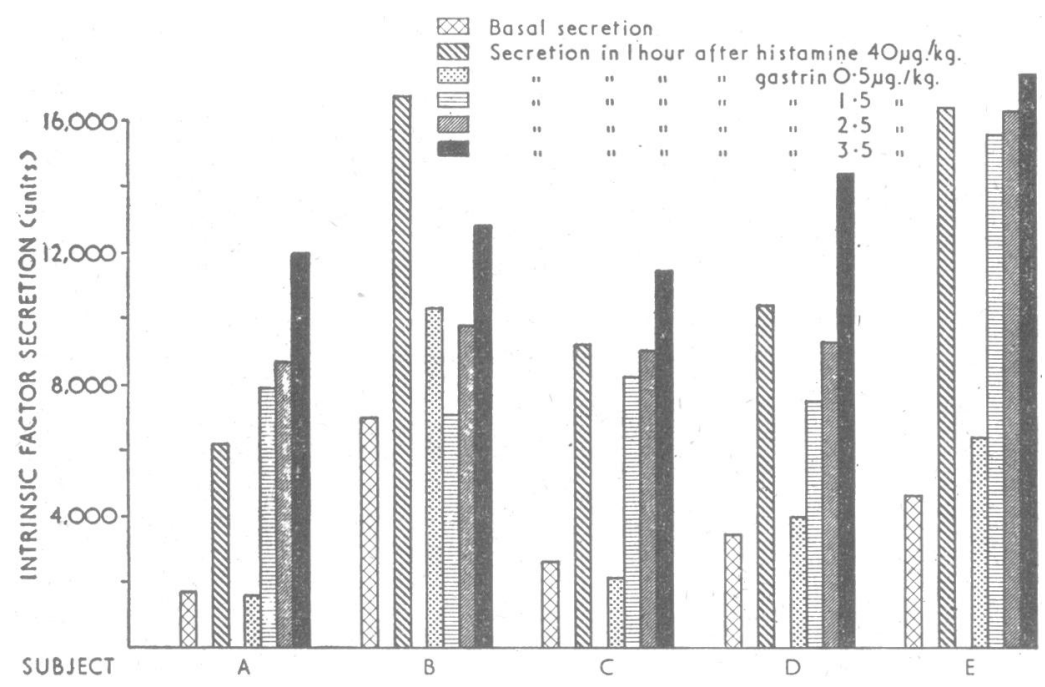

FIG. 1.-Effect of histamine and of increasing doses of gastrin I and II on the secretion of intrinsic factor in five normal subjects. The basal secretion has been calculated for one hour to facilitate comparison.

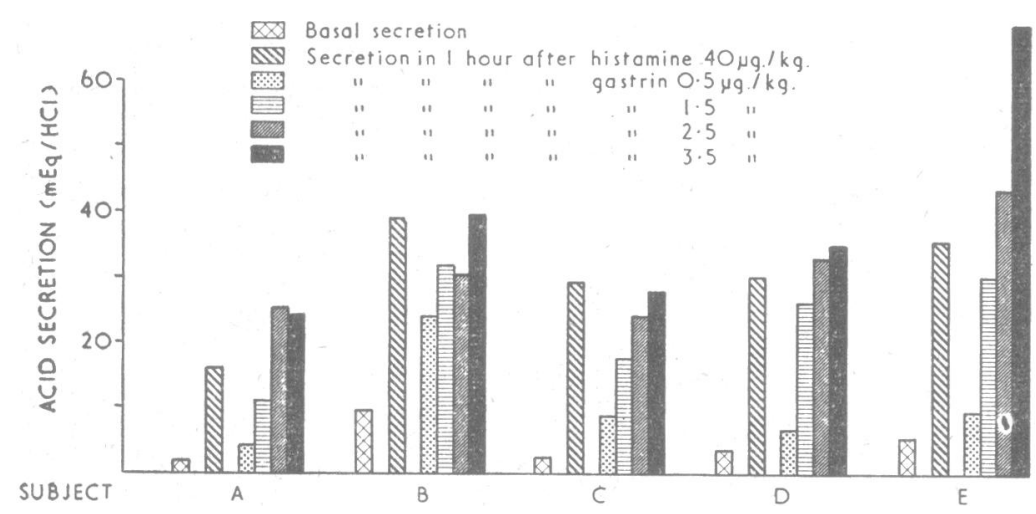

FIG. 2.-Effect of histamine and of increasing doses of gastrin I and II on the secretion of acid in five normal subjects. The basal secretion has been calculated for one hour to facilitate comparison. charcoal to remove unbound ${ }^{58} \mathrm{Co}$-vitamin- $\mathrm{B}_{12}$ the tubes were centrifuged and the radioactivity in 4-ml. aliquots of the clear supernatant was counted in a well-type scintillation counter. The content of intrinsic factor per $\mathrm{ml}$. of gastric juice was calculated by subtracting the amount of ${ }^{58} \mathrm{Co}$-vitamin- $\mathrm{B}_{12}$ bound by gastric juice in the presence of serum containing antibody to intrinsic factor, from the amount bound by gastric juice in the presence of pooled normal serum. In accordance with Ardeman and Chanarin (1963) 1 unit of intrinsic factor was defined as that amount which bound $1 \mu \mathrm{mg}$. of ${ }^{58} \mathrm{Co}-$ vitamin- $B_{12}$.

\section{Results}

Whereas all the subjects found the augmented histamine test distinctly unpleasant, none experienced any reaction or pain from the injection of gastrin.

Table I presents the detailed results of the secretion of intrinsic factor and acid during the phases of the tests. It is clear that both gastrin and histamine enhanced the secretion of intrinsic factor and that the effect increased with increasing doses of gastrin.

Fig. 1 shows the amounts of intrinsic factor secreted in the hour after stimulation in the five subjects. Little, if any, increase was evident after $0.5 \mu \mathrm{g}$. of gastrin per $\mathrm{kg}$. However, larger doses caused a distinct increase in the secretion of intrinsic factor, and with $2.5 \mu \mathrm{g}$. $/ \mathrm{kg}$. the effect was of the same order as with "maximal" histamine stimulation. With $3.5 \mu \mathrm{g} . / \mathrm{kg}$. all but one of the subjects secreted more intrinsic factor than with histamine and all secreted more than with $2.5 \mu \mathrm{g}$. of gastrin per kg. Thus there was no evidence that the secretion of intrinsic factor after the larger dose was the highest of which the stomach was capable.

The increase in secretion of intrinsic factor which followed stimulation with gastrin and histamine was due both to a greater secretory flow and to higher concentration of intrinsic factor in the gastric juice (Table II).

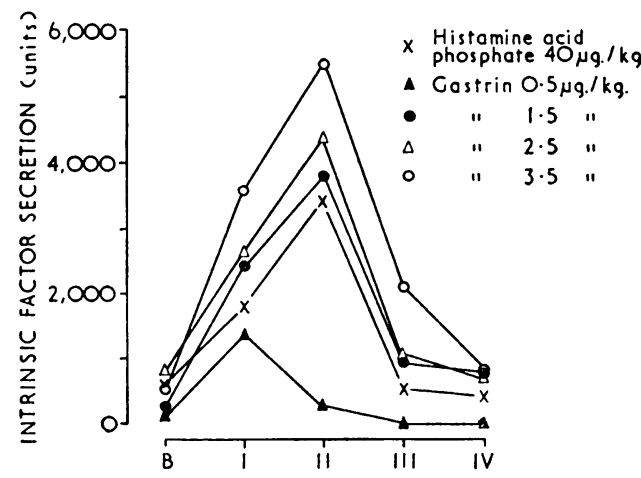

FIG. 3.-Secretion of intrinsic factor in subject $A$ after stimulation with histamine and with increasing doses of gastrin I and II. $B=$ basal secretion calculated for 15 -minutes; I-IV are the four successive 15-minute periods after stimulation.

TABLE II.-Concentration of Intrinsic Factor (I.F.) in the Gastric fuice and the Volume of Fuice Sccreted Before and After Stimulation with Histamine Acid Phosphate and with Gastrin in Subject $A$

\begin{tabular}{|c|c|c|c|c|c|c|c|c|c|c|c|}
\hline \multirow{3}{*}{ Stimulus } & & \multirow{2}{*}{\multicolumn{2}{|c|}{ Basal }} & \multicolumn{8}{|c|}{ Fifteen-minute Periods } \\
\hline & & & & \multicolumn{2}{|c|}{1} & \multicolumn{2}{|c|}{2} & \multicolumn{2}{|c|}{3} & \multicolumn{2}{|c|}{4} \\
\hline & & $\underset{\text { (units/ml.) }}{\text { I.F. }}$ & $\begin{array}{l}\text { Vol.; } \\
\text { (ml.) }\end{array}$ & $\underset{\text { (units/ml.) }}{\text { I.F. }}$ & $\begin{array}{l}\text { Vol. } \\
\text { (ml.) }\end{array}$ & $\underset{\text { (units/ml.) }}{\text { I.F. }}$ & $\begin{array}{l}\text { Vol. } \\
\text { (ml.) }\end{array}$ & $\begin{array}{c}\text { I.F. } \\
\text { (units/ml.) }\end{array}$ & $\begin{array}{l}\text { Vol. } \\
\text { (ml.) }\end{array}$ & $\underset{\text { (units/ml.) }}{\text { I.F. }}$ & $\begin{array}{l}\text { Vol. } \\
\text { (ml.) }\end{array}$ \\
\hline $\begin{array}{ccc}\text { Histamine } 40 & \mu \mathrm{g} . / \mathrm{kg} . \\
\text { Gastrin } 0.5 & \text { " } \\
\Rightarrow \quad 1.5 & " \\
\Rightarrow & 2.5 & \text { " } \\
\Rightarrow & 3.5 & \text { " }\end{array}$ & $\begin{array}{l}\because \\
\therefore \\
\therefore\end{array}$ & $\begin{array}{r}37 \\
9 \\
28 \\
47 \\
55\end{array}$ & $\begin{array}{r}17 \\
6 \\
11 \\
18 \\
9\end{array}$ & $\begin{array}{r}130 \\
110 \\
120 \\
83 \\
134\end{array}$ & $\begin{array}{l}14 \\
13 \\
20 \\
31 \\
27\end{array}$ & $\begin{array}{r}57 \\
36 \\
139 \\
113 \\
127\end{array}$ & $\begin{array}{r}60 \\
8 \\
27 \\
39 \\
43\end{array}$ & $\begin{array}{r}20 \\
1 \\
58 \\
35 \\
48\end{array}$ & $\begin{array}{r}28 \\
6 \\
17 \\
30 \\
45\end{array}$ & $\begin{array}{r}18 \\
0 \\
53 \\
21 \\
25\end{array}$ & $\begin{array}{l}24 \\
10 \\
14 \\
32 \\
30\end{array}$ \\
\hline
\end{tabular}


In contrast to the secretion of intrinsic factor the secretion of acid was augmented even with the smallest dose of gastrin employed, and increased with larger doses (Fig. 2). The output of acid after $2.5 \mu \mathrm{g}$. of gastrin per $\mathrm{kg}$. was of the same magnitude as in the augmented histamine test. It was noteworthy that four of the five subjects secreted more acid in response to $3.5 \mu \mathrm{g}$. of gastrin per $\mathrm{kg}$. than after histamine. Larger doses have so far not been used.

Fig. 3 shows the onset and duration of gastrin stimulation in subject A. The secretion of intrinsic factor began to rise in the first 15-minute period but did not reach a peak until the second 15 minutes. This was the general pattern in all the subjects, and usually basal levels were reached by the last 15 minutes of the test (Table I). By contrast, acid secretion was still elevated at the end of the test (Table I). This difference in the patterns of acid and intrinsic-factor secretion was evident both with gastrin and with histamine stimulation (Table I).

\section{Discussion}

In this study $3.5 \mu \mathrm{g}$. per $\mathrm{kg}$. of a combination of gastrin I and II proved a marginally better stimulant of intrinsic-factor secretion than histamine acid phosphate $40 \mu \mathrm{g} . / \mathrm{kg}$. It was also possible to enhance acid secretion to a slightly greater extent than with histamine in four of the five subjects. Similar results for the acid secretion have been reported with pure gastrin II (Makhlouf et al., 1964). While this paper was being prepared, Irvine (1965), in a preliminary communication, reported effects of gastrin I and II on the secretion of intrinsic factor which were very similar to those described in this paper.

No side-effects were observed, and gastrin thus appears to be an effective and safe gastric stimulant. It should prove particularly valuable in patients with suspected pernicious anaemia in whom advanced age or concomitant disease militate against the use of histamine. The scarcity and relatively high cost of gastrin have yet to be overcome.

The present results give no reason to believe that the rate of secretion of intrinsic factor after gastrin $3.5 \mu \mathrm{g} . / \mathrm{kg}$., although greater than that achieved with histamine, represents the maximum secretory capacity of the stomach. It would be of interest to determine the highest output of intrinsic factor of which the stomach is capable and the dose of gastrin required to achieve this effect. This aspect is currently being investigated. For routine purposes, however, it may be sufficient to aim at producing a degree of stimulation at least corresponding to that of the augmented histamine test. The present experiments indicate that this effect can be obtained with a dose of $3.5 \mu \mathrm{g} . / \mathrm{kg}$.

A preparation of gastrin I and II from one single batch was used in this study. However, it is known that this preparation also contains other polypeptides, and hence different batches may vary in their biological activity. This potential source of error is now being eliminated by biological assay before distribution (Dr. O. Bremer, personal communication). Synthetic gastrin (Anderson et al., 1964), when commercially available, should overcome this difficulty.

\section{Summary}

Five normal subjects each underwent five experiments: one augmented histamine test and four tests in which a combination of gastrin I and II in varying doses was used to stimulate gastric secretion. The intrinsic-factor content of the gastric juice was measured by immuno-assay, and gastric acidity was also estimated. The secretion of intrinsic factor and of acid was determined during 30 minutes before and 60 minutes after administration of the drugs.

Four of the five subjects secreted more intrinsic factor after gastrin $3.5 \mu \mathrm{g} . / \mathrm{kg}$. than in the augmented histamine test, but there was no evidence that with this dose of gastrin the rate of secretion of intrinsic factor had reached its upper limit. Acid secretion showed a similar response.

Smaller doses of gastrin caused less stimulation, and the smallest dose used, $0.5 \mu \mathrm{g} . / \mathrm{kg}$., had little effect on the secretion of intrinsic factor, although acid secretion was enhanced. Both gastrin and histamine had a less sustained effect on intrinsicfactor secretion than on acid secretion.

No side-effects were encountered with gastrin, and it is suggested that this substance is a useful alternative to histamine in tests of intrinsic-factor secretion.

We are grateful to Professor L. J. Witts for the use of the facilities of his department in this study; to Dr. O. Bremer, of Leo Pharmaceuticals, Copenhagen, for the supply of the preparation of gastrin I and II ; and to our medical colleagues who were subjected to the tests. Miss L. Butler and Miss J. Birtles provided technical assistance and Mr. Brian Purvis prepared the graphs.

The work was supported in part by a grant from the Medical Research Council.

\section{REFERENCES}

Abels, J., Bouma, W., and Nieweg, H. O. (1963). Biochim. biophys. Acta (Amst.), 71, 227.

Anderson, J. C., Barton, M. A., Gregory, R. A., Hardy, P. M., Kenner, G. W., Macleod, J. K., Preston, J., Sheppard, R. C., and Morley, J. S. (1964). Nature (Lond.), 204, 933.

Ardemann, S., and Chanarin, I. (1963) Lancet, 2, 1350.

Castro, Z., and Glass, G. B. J. (1962). Clin. Res. Proc., 10, 197.

Gregory, R. A., and Tracy, H. J. (1964). Gut, 5, 103.

Irvine, W. J. (1965). Lancet, 1, 736

Jeffries, G. H., Sleisenger, M. H., and Benjamin, L. L. (1963). 7. clin. Invest., 42, 442.

Kay, A. W. (1953). Brit. med. 7., $2,77$.

Makhlouf, G. M., McManus, J. P. A., and Card, W. I. (1964). Lancet,

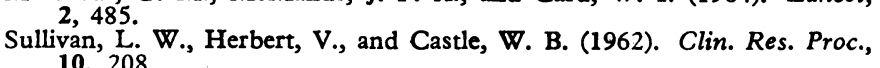

